\title{
Bartonella spp. in cats
}

Paulè Drigotaitè,

Miglè Razgūnaitè,

Jana Radzijevskaja*,

Algimantas Paulauskas

Vytautas Magnus University,

K. Donelaičio g. 58, Kaunas 44248,

Lithuania
Bartonella spp. are gram-negative, haemotropic bacteria infecting both a wide range of animals and humans. The currently known vectors of Bartonella spp. are fleas, ticks, lice, and sand flies. Domestic cats are the main reservoir for B. henselae, B. clarridgeiae, and B. koehlerae. Bartonella infections in cats vary from mild to deadly and, since they usually have no specific symptoms, they are often underestimated. This review provides information on Bartonella infections in cats, their biology, and pathogenicity.

Keywords: bartonella, cats, vector-borne zoonotic diseases, pathogenesis

\section{INTRODUCTION}

Most of the human diseases are zoonoses, which are usually vector-borne (VBDs) (Ehlers et al., 2020). These diseases, especially companion animal VBDs, have a major impact on the welfare of pets and humans due to the close association among them (Latrofa et al., 2020; Maggi, Krämer, 2019). Cats are considered less susceptible to vector-borne diseases than dogs, therefore there is less data and studies regarding feline vectorborne diseases (FeVBDs). Despite the growing distribution areas of feline vector-borne pathogens, especially Bartonella spp., they are underestimated and frequently unsuspected by clinicians (Latrofa et al., 2020; Morelli et al., 2019). Such factors as globalization, increased travel, climate change, and international trade of goods favour the spread of vectors and pathogens they transmit (Ehlers et al., 2020; Maggi, Krämer, 2019; Morelli et al., 2019). Effective control of vector-borne diseases, including bartonellosis, can only be

\footnotetext{
*Corresponding author. Email: jana.radzijevskaja@vdu.lt
}

achieved by a thorough knowledge of the infectious agents, their vectors, and major hosts. As no obvious agreement has been reached among veterinary practitioners regarding many issues concerning Bartonella infections in cats (Brown et al., 2005), it is necessary to study and spread information about these pathogens in cats. This review provides an overview of cat-infecting Bartonella species, their biology, pathogenicity, treatment, and prevention.

\section{Bartonella vectors and hosts}

Bartonella spp. are relatively diverse and have a global distribution. They infect a wide range of wild and domestic animals, including bats, birds, canids, cattle, deer, felids, horses, marine mammals, rodents, sheep, and reptiles. Bartonella spp. is also found in humans (Corduneanu et al., 2018; Diaz et al., 2012) (Table). These bacteria are adapted and co-evolved with specific reservoir hosts and, possibly, arthropod vectors. Although this ability is one of the ways to ensure successful transmission, accidental hosts are also possible (Álvarez-Fernández et al., 2018; Kosoy, 
Table. Domestic cat-infecting Bartonella species, their known and suspected vectors, other hosts, and diseases they cause to humans

\begin{tabular}{|c|c|c|c|c|}
\hline $\begin{array}{c}\text { Bartonella } \\
\text { species }\end{array}$ & Vectors & Other hosts & Diseases in humans & References \\
\hline $\begin{array}{c}\text { Bartonella } \\
\text { henselae }\end{array}$ & $\begin{array}{l}\text { Cat and dog fleas, } \\
\text { biting flies, ticks } \\
\text { (Ixodes spp., } \\
\text { Rhipicephalus spp., } \\
\text { Dermacentor spp.), } \\
\text { lice }\end{array}$ & $\begin{array}{l}\text { Humans, } \\
\text { guinea pigs, } \\
\text { rabbits, dogs, } \\
\text { birds, squir- } \\
\quad \text { rels }\end{array}$ & $\begin{array}{l}\text { CSD, Parinaud's } \\
\text { oculoglandular syn- } \\
\text { drome, endocarditis, } \\
\text { bacillary peliosis, } \\
\text { bacillary angiomato- } \\
\text { sis, neuroretinitis }\end{array}$ & $\begin{array}{c}\text { Billeter et al., 2008; } \\
\text { Chang et al., 2001; } \\
\text { Chung et al., 2004; Guptill, } \\
\text { 2003; Mascarelli et al., 2014; } \\
\text { Mazur-Melewska et al., 2015; } \\
\text { Sanogo et al., 2003; Tsai et al., } \\
\text { 2011; Wikswo et al., } 2007\end{array}$ \\
\hline $\begin{array}{l}\text { Bartonella } \\
\text { clarridgeiae }\end{array}$ & $\begin{array}{l}\text { Cat and dog fleas, } \\
\text { cattle tick }\end{array}$ & $\begin{array}{l}\text { Humans, } \\
\text { dogs, cattle, } \\
\text { voles, cotton } \\
\text { rats }\end{array}$ & $\begin{array}{l}\text { CSD, aortic root ab- } \\
\text { scess, endocarditis }\end{array}$ & $\begin{array}{l}\text { Guptill, 2003; Logan et al., } \\
\text { 2019; Mosbacher et al., 2011; } \\
\text { Tsai et al., } 2011\end{array}$ \\
\hline $\begin{array}{l}\text { Bartonella } \\
\text { koehlerae }\end{array}$ & Cat flea & $\begin{array}{l}\text { Humans, } \\
\text { dogs, birds }\end{array}$ & $\begin{array}{l}\text { CSD, endocarditis, } \\
\text { neuropathy }\end{array}$ & $\begin{array}{l}\text { Breitschwerdt et al., 2010; } \\
\text { Cheslock, Embers, 2019; } \\
\text { Chomel et al., 2006; Mascarel- } \\
\text { li et al., } 2014\end{array}$ \\
\hline $\begin{array}{c}\text { Bartonella } \\
\text { bovis }\end{array}$ & Cattle tick, flies & Cattle & - & Guptill, 2010; Kho et al., 2015 \\
\hline $\begin{array}{c}\text { Bartonella } \\
\text { quintana }\end{array}$ & $\begin{array}{l}\text { Cat and squirrel } \\
\text { fleas, head and } \\
\text { body lice, ticks (Ix- } \\
\text { odes spp., Derma- } \\
\text { centor spp.) }\end{array}$ & $\begin{array}{l}\text { Humans, } \\
\text { squirrels, } \\
\text { monkeys }\end{array}$ & $\begin{array}{l}\text { Bacillary angioma- } \\
\text { tosis, trench fever, } \\
\text { endocarditis, lym- } \\
\text { phadenopathy }\end{array}$ & $\begin{array}{c}\text { Billeter et al., 2008; } \\
\text { Chang et al., 2001; Mos- } \\
\text { bacher et al., 2011; Raoult, } \\
\text { Roux, 1999; Sasaki et al., 2006; } \\
\text { Tsai et al., } 2011\end{array}$ \\
\hline
\end{tabular}

Goodrich, 2019; Tay et al., 2018). Domestic cats (Felis catus) are the main reservoir for $B$. henselae, B. clarridgeiae, and B. koehlerae, the causal agents of human cat scratch disease (CSD). Other cat infecting Bartonella species include B. bovis and B. quintana, (Lappin, 2018). Bartonella spp. are mainly transmitted by fleas. The main Bartonella henselae vector is the cat flea Ctenocephalides felis. Ctenocephalides felis is also suspected to transmit Bartonella quintana (Iannino, 2018). However, other arthropods, such as sand flies, ticks, or lice have also been shown to transmit these pathogens (Diaz et al., 2012). Several species of ticks of the genera Ixodes and Dermacentor have been shown to harbour Bartonella DNA (Billeter et al., 2008; Chomel, Kasten, 2010). As the main vectors are fleas, Bartonella infections are seasonal and depend on the location just as the flea infesta- tion rates. Prevalence of the diseases caused by Bartonella is higher in warm geographical areas with high humidity (Abdullah et al., 2019; Hobson et al., 2017). Alternative transmission types may involve cat scratches and bites (particularly important in developing CSD) or blood transfusion and transmission through needle stick injury (Almeida et al., 2019). After a cat scratch, the wound becomes infected with cat flea faeces containing Bartonella spp. bacteria. Bartonella henselae can remain viable in flea faeces for over 72 hours (Klotz et al., 2011; Kosoy, Goodrich, 2019).

\section{Pathogenesis of Bartonella infection}

Bartonella spp. are small, gram-negative, haemotropic bacteria, members of the class Alphaproteobacteria. These bacteria are slow-growing 
intracellular and facultative (Donovan et al., 2018; Hobson et al., 2017). There are numerous factors that determine the level of infection by Bartonella spp. Some of them include the cat's immune status, living conditions, Bartonella strain virulence, and the infection phase (Álvarez-Fernández et al., 2018; Mazurek et al., 2020). Successful Bartonella spp. persistence in the environment is mainly a result of arthropods having access to reservoir animals that are bacteraemic for a long enough time to become infected (Kosoy, Goodrich, 2019). The long-term bacteraemia in cats can last for months or even years. It is achieved by a relapsing infection without any particular symptoms, damaging the organs in a harmful way instead (Chomel et al., 2009; Donovan et al., 2018; Iannino et al., 2018).

The main stages of infection with Bartonella bacteria include transmission by the vector and infection of the reservoir host (Harms, Dehio, 2012). When a blood-sucking arthropod vector feeds on an infected cat, Bartonella bacteria enter the vector gut and form biofilms for protection from the toxic environment (Okaro et al., 2017). They reproduce in the gut and are later released to the salivary glands. From the glands, Bartonella spp. can infect new cats or humans during blood-sucking vector feeding (Liu, Bonnet, 2014). After infecting cats, Bartonella bacteria must cope with an opposite environment as there is a deprivation of heme and iron in the mammalian host (Okaro et al., 2017). Hemin is required for Bartonella spp. growth, especially for $B$. quintana and $B$. henselae, as it is an important source of iron and porphyrin (Alsmark et al., 2004; Chomel et al., 2009). Hemin-binding proteins (Hbps) and heminuptake genes are necessary not only to acquire hemin but also to combat toxic concentrations of heme in the cat flea vector (Tu et al., 2017).

Bartonella bacteria usually infect erythrocytes or endothelial cells by conventional phagocytosis or invasome-mediated mechanism using type IV or type $\mathrm{V}$ secretion systems (Almeida et al., 2019; Alsmark et al., 2004; Tamarit et al., 2018). Non-haemolytic persistence in blood cells enables the transmission of the bac- teria by the blood-sucking arthropods (Kosoy, Goodrich, 2019). If the bacteria are cleared from the bloodstream, they can grow in endothelial cells, seed into the blood, and invade erythrocytes again (Chomel et al., 2009; Okaro et al., 2017). To infect endothelial cells, Bartonella spp. use phage-like gene transfer agents. a-proteobacteria usually have RcGTA that are broadly distributed between species. However, Bartonella spp. have specific and highly conserved gene transfer agents (BaGTA) (Tamarit et al., 2018; Tay et al., 2018; Québatte, Dehio, 2019). In cats, a chronic invasion of erythrocytes is more likely to happen than an invasion of endothelial cells (Álvarez-Fernández et al., 2018).

Phagocytes are the first line of immune defence against Bartonella infection. However, antibodies are usually evaded as they cannot reach the intracellular bacteria and rarely target infected erythrocytes, which have a similar lifespan to the uninfected ones (Chomel et al., 2009). Another line of defence is pattern-recognition receptors - TLRs. Bartonella spp. pathogen-associated molecular patterns (PAMPs), such as lipopolysaccharides, flagella and adhesins, have an unusual structure and their expression can be suppressed. This is the reason they are weakly recognized by TLRs and do not induce production of pro-inflammatory cytokines (Okaro et al., 2017). Infection with one Bartonella species has not been shown to provide immunity to another species. Co-infection in cats with two Bartonella species or genotypes, as well as co-infection with other pathogens, is also possible (Boulouis et al., 2005).

\section{Bartonella species infecting cats}

\section{Bartonella henselae}

Bartonella henselae is grouped into Genotype I and Genotype II based on 16S-rDNA sequences (Duscher et al., 2018). These strains have different point mutations, protein profiles, host specificity, prevalence, and pathogenicity (Castel et al., 2019; Chomel et al., 2009; Diaz et al., 2012; Iredell et al., 2003; Mietze et al., 2011). Genotype I (Houston) is more often found in humans and is prevalent in Asia. Genotype II (Marseille) is mostly found 
in cats and is prevalent in Europe, Australia, and the United States (Bouchouicha et al., 2009; Mazurek et al., 2020). It is also considered to be less pathogenic as Genotype I is more likely to cause human CSD (Maggi et al., 2013). In the US, 30$60 \%$ of domestic cats are infected with $B$. henselae (Alsmark et al., 2004). In Europe, prevalence of Bartonella henselae in cats ranges from $0 \%$ to 71.4\% (Álvarez-Fernández et al., 2018).

\section{Bartonella clarridgeiae}

Bartonella clarridgeiae is second most commonly detected Bartonella species responsible for CSD (Kordick et al., 1997). It is also one of the few Bartonella species possessing flagella (Minnick, Anderson, 2015). An extremely high number of these bacteria is found in the domestic cat population. Infection is also possible between other members of the Felidae family, e.g., puma. Bacterium is also found in members of the canine family (Boulouis et al., 2005). It was first isolated in 1995 by the researcher Jill Clarridge and colleagues from cat blood, which was linked to human infection with CSD caused by $B$. henselae. Both species of this bacterial genus are widespread, with recorded cases in domestic cats in North America, Europe, Asia, and Australia (Clarridge et al., 1995). Studies in cats with bacteraemia in Western Europe - France and the Netherlands have shown 30 to $36 \%$ infection with B. larridgeiae (Gurfield, 2001).

\section{Bartonella koehlerae and Bartonella bovis}

As mentioned above, Bartonella koehlerae and Bartonella bovis have been detected in cats several times. Cats are considered to be the main reservoir of $B$. koehlerae, which has been reported to cause human endocarditis (Avidor et al., 2004). Domestic cats are also principal reservoir hosts for $B$. koehlerae. Infected cats are thought to rarely develop clinical signs. Although chronic relapsing bacteraemia can frequently be detected in infected cats, potential long-term consequences of relapsing bacteraemia are unknown (Álvarez-Fernández et al., 2018). As for B. bovis, it is mainly associated with cattle (Breitschwerdt et al., 2010; Cher- ry et al., 2009). The effect of Bartonella infections in cattle, if any, is unknown. Because $B$. bovis is very common in some herds, it is difficult to attribute clinical signs to this organism. In one study, B. bovis was suggested as the cause of endocarditis in two older cows. The role of domestic cats in the epidemiology of B. bovis (formerly B. weissii) has not been clearly established, as only a limited number of isolates have been obtained from cats in Illinois and Utah (Regnery et al., 2000). There is a relatively low amount of studies on the manifestations of these Bartonella species in cats and humans.

\section{Bartonella quintana}

Bartonella quintana is the causative agent of trench fever in humans (Stützer, Hartmann, 2012). This disease is not necessarily fatal. However, it results in a fever that lasts a few days (Sander et al., 1997). Cats are only an accidental host of this Bartonella species, as the main reservoir hosts are humans (Iannino et al., 2018). B. quintana is often associated with homelessness, alcoholism, and poverty (Chang et al., 2001; Billeter et al., 2008).

\section{Clinical manifestations of cat-associated Bartonella infection and treatment}

The severity of the diseases caused by Bartonella spp. may range from asymptomatic to fatal depending on the host's immune status (Amer, Tugal-Tutkun, 2017). In cats, Bartonella spp. infection usually causes no particular symptoms. Clinical symptoms are more likely to develop in young kittens (Abreu-Yanes et al., 2020). In more severe cases, the infection can result in lymphadenopathy, endocarditis, myocarditis, hyperglobulinemia, chronic relapsing bacteraemia, or even severe haemolytic anaemia. The bacteraemia is more frequently observed in stray cats. (Abdullah et al., 2019; ÁlvarezFernández et al., 2018; Chomel et al., 2009). Most of the clinical symptoms are caused by $B$. quintana and B. henselae (Almeida et al., 2019). Treatment of sick cats usually consists of administering one or few antibiotics for 
a certain amount of time. Most often recommended antibiotics include doxycycline, fluoroquinolones, enrofloxacin, oribifloxacin, or pradofloxacin. Enrofloxacin is known to be useful for fever treatment (Lappin, 2018; Lappin et al., 2020). Fluoroquinolones are usually used in combination with other antibiotics (Biswas, Rolain, 2010). It is not recommended to use rifampicin or azithromycin for cat treatment (Álvarez-Fernández et al., 2018; Lappin, 2018).

Cat-scratch disease usually develops in immunocompetent humans and more commonly affects children and teenagers (Amer, Tugal-Tutkun, 2017). The symptoms include erythematous papule at the site of inoculation, swelling of lymph nodes, fever, aching, malaise, or anorexia (Canneti et al., 2019; Hobson et al., 2017; Klotz et al., 2011). Other less common symptoms may include myalgia, arthralgia, and hepatosplenomegaly (Johnson, 2020). Ocular bartonellosis, such as Parinaud oculoglandular syndrome and neuroretinitis, can also occur (Amer, Tugal-Tutkun, 2017; Klotz et al., 2011). Other diseases that $B$. henselae, B. clarridgeiae, and B. koehlerae may cause involve bacillary peliosis and angiomatosis, endocarditis, pneumonia, osteomyelitis, encephalitis, meningitis, and neuropathy (Cheslock, Embers, 2019; Deng et al., 2018; Johnson, 2020; Klotz et al., 2011; Ksiaa et al., 2019). Since CSD is considered to be a self-limiting disease, the use of antibiotics is not recommended in patients with mild symptoms. Patients that develop complications such as endocarditis or hepatic peliosis are usually treated with gentamicin, doxycycline, rifampicin, or erythromycin as the bacteria are susceptible to beta-lactams, aminoglycosides, macrolides, and tetracyclines (Almeida et al., 2019; Hobson et al., 2017).

\section{Diagnostics and prevention}

Diagnostic methods for Bartonella spp. in cats include PCR, culture, and serology methods (Lappin et al., 2020). Formerly, Bartonella spp. isolation from blood was considered to be the golden standard (Breitschwerdt et al., 2010). However, culturing these bacteria is a challenge. Bacteria growth takes a long time, and they require a specific media and an environment rich in $\mathrm{CO}_{2}$ (Agan, Dolan, 2002). Currently, PCR is more often used than culture methods. PCR methods target genes, such as gltA, groEL, pap31, ftsZ, 16rRNA, and 16S23S ITS region (Billeter et al., 2008; Urdapilleta et al., 2020). Serological methods include ELISA, immunofluorescent antibody assays. However, cross-reactions can occur and these methods are questionable in diagnosing active infections (Bergmans et al., 1997; Maurin et al., 1997).

The most important preventive measure of Bartonella spp. infections in cats is ectoparasitic treatment and control (Pennisi et al., 2013). Animal lifestyle, grooming, and behavioural prophylaxis also have a huge impact on the occurrence of Bartonella spp. infections (Amer, Tugal-Tutkun, 2017; Duscher et al., 2018; Ksiaa et al., 2019; Maggi, Krämer, 2019). To minimize the risk of these infections, adopting healthy seronegative adult cats rather than kittens should also be considered (Boulouis et al., 2005).

\section{CONCLUSIONS}

Vector-borne diseases, especially feline vector-borne diseases, are emerging due to climate change and other ecological factors. Bartonella spp., one of the most abundant and diverse zoonotic vector-borne pathogens, is often underestimated because of the non-specific symptoms. Domestic cats are the natural reservoir of Bartonella henselae and Bartonella clarridgeiae. To prevent the spread of such pathogens, it is important to establish ectoparasitic treatment, animal grooming, behavioural prophylaxis, and to study factors involved in keeping the bacteria persistent in the environment.

Received 8 April 2021 Accepted 12 May 2021 


\section{References}

1. Abdullah S, Helps C, Tasker S, Newbury H, Wall R. Pathogens in fleas collected from cats and dogs: distribution and prevalence in the UK. Parasit Vectors. 2019; 12(1).

2. Abreu-Yanes E, Abreu-Acosta N, Kosoy M, Foronda P. Molecular detection of Bartonella henselae, Bartonella clarridgeiae and Rickettsia felis in cat and dog fleas in Tenerife, Canary Islands, Spain. J Vector Ecol. 2020; 45(2): 233-240.

3. Agan BK, Dolan MJ. Laboratory diagnosis of Bartonella infections. Clin Lab Med. 2002; 22: 937-962.

4. Almeida K. De, Drummond MR, Velho PENF. Cutaneous manifestations of bartonellosis. An Bras Dermatol. 2019; 94(5): 594-602.

5. Alsmark CM, Frank AC, Karlberg EO, Legault BA, Ardell DH, Canbäck B, et al. The louse-borne human pathogen Bartonella quintana is a genomic derivative of the zoonotic agent Bartonella henselae. Proc Natl Acad Sci USA. 2004; 101(26).

6. Álvarez-Fernández A, Breitschwerdt EB, Solano-Gallego L. Bartonella infections in cats and dogs including zoonotic aspects. Parasit Vectors. 2018; 24: 1-21.

7. Amer R, Tugal-Tutkun I. Ophthalmic manifestations of Bartonella infection. Curr Opin Ophthalmol. 2017; 28(6): 607-12.

8. Avidor B, Graidy M, Efra G, Leibowitz C, Shapira G, Schattner A, Zimhony O, et al. Bartonella koehlerae, a new cat-associated agent of culture-negative human endocarditis. J Clin Microbiol. 2004; 42: 3462-8.

9. Bergmans AMC, Peeters MF, Schellekens JF, Vos MC, Sabbe LJ, Ossewaarde JM, et al. Pitfalls and fallacies of cat scratch disease serology: evaluation of Bartonella henselae-based indirect fluorescence assay and enzyme-linked immunoassay. J Clin Microbiol. 1997; 35(8): 1931-7.

10. Billeter SA, Levy MG, Chomel BB, Breitschwerdt EB. Vector transmission of Bartonella spe- cies with emphasis on the potential for tick transmission. Med Vet Entomol. 2008; 22: 1-15.

11. Biswas S, Rolain J. Bartonella infection: treatment and drug resistance. Future Microbiol. 2010; 5(11): 1719-31.

12. Bouchouicha R, Durand B, Monteil M, Chomel BB, Berrich M, Arvand M, et al. Epidemiology of feline and human Bartonella henselae. Emerg Infect Dis. 2009; 15(5): 10-3.

13. Boulouis H, Chang CC, Henn JB, Kasten RW, Chomel BB. Factors associated with the rapid emergence of zoonotic Bartonella infections. Vet Res. 2005; 36: 383-410.

14. Breitschwerdt EB, Maggi RG, Mozayeni BR, Hegarty BC, Bradley M, Mascarelli PE. PCR amplification of Bartonella koehlerae from human blood and enrichment blood cultures. Parasit Vectors. 2010; 1-9.

15. Brown RR, Elston TH, Evans L, Glaser C, Gulledge ML, Jarboe L, et al. Feline zoonoses guidelines from the American Association of Feline Practitioners. J Feline Med Surg. 2005; 7(4): 243-74.

16. Canneti B, Cabo-López I, Puy-Núñez A, García JC, Cores FJ, Trigo M, et al. Neurological presentations of Bartonella henselae infection. Neurol sci. 2019; 40: 261-8.

17. Castel A, Olby NJ, Breitschwerdt EB, Thomas B, Maggi RG, Shelton GD. Co-infection with Bartonella henselae and Sarcocystis sp. in a 6-year-old male neutered domestic longhair cat with progressive multifocal neurological signs. Vet Q. 2019; 39(1): 168-73.

18. Chang CC, Chomel BB, Kaster RW, Romano V, Tietze N. Molecular Evidence of Bartonella spp. in questing adult Ixodes pacificus ticks in California. J Clin Microbiol. 2001; 39(4): 1221-6.

19. Cherry NA, Maggi RG, Cannedy AL, Breitschwerdt EB. PCR detection of Bartonella bovis and Bartonella henselae in the blood of beef cattle. Vet Microbiol. 2009; 135: 308-12.

20. Cheslock MA, Embers ME. Human bartonellosis: an underappreciated publick health problem? Trop Med Infect Dis. 2019; 4. 
21. Chomel BB, Kasten RW. Bartonellosis, an increasingly recognized zoonosis. J Appl Microbiol. 2010; 109: 743-50.

22. Chomel BB, Boulouis HJ, Maruyama S, breitschwerdt EB. Bartonella sp. in pets and effect on human health. Emerg Infect Dis. 2006; 12(3): 389-94.

23. Chomel BB, Boulouis HJ, Breitschwerdt EB, Kasten RW, Vayssier-Taussat M., Birtles RJ, et al. Ecological fitness and strategies of adaptation of Bartonella species to their hosts and vectors. Vet Res. 2009; 40(2).

24. Chung CY, Kasten RW, Paff SM, Van-Horn BA, Vayssier-Taussat M., Boulouis HJ, et al. Bartonella spp. DNA associated with biting flies from California. Emerg Infect Dis. 2004; 10(7).

25. Clarridge JE, Raich TJ, Pirwani D, Simon B, Tsai L, Rodriguez-Barradas C, et al. Strategy to detect and identify Bartonella species in routine clinical laboratory yields Bartonella henselae from human immunodeficiency virus-positive patient and unique Bartonella strain from his cat. J Clin Microbiol. 1995; 33(8): 2107-13.

26. Corduneanu A, Sándor AD, Ionică AM, Hornok S, Leitner N, Bagó Z, et al. Bartonella DNA in heart tissues of bats in central and eastern Europe and a review of phylogenetic relations of bat-associated bartonellae. Parasit Vectors. 2019; 11 .

27. Deng H, Pang Q, Zhao B, Vayssier-Taussat M. Molecular mechanisms of Bartonella and mammalian erythrocyte interactions: a review. Front Cell Infect Microbiol. 2018; 8 (December): 1-11.

28. Diaz MH, Bai Y, Malania L, Winchell JM, Kosoy MY. Development of a novel genusspecific real-time PCR assay for detection and differentiation of Bartonella species and genotypes. J Clin Microbiol. 2012; 50(5): 1645-9.

29. Donovan TA, Balakrishnan N, Barbosa IC, McCoy T, Breitschwerdt EB, Fox PR. Bartonella spp. as a possible cause or cofactor of feline endomyocarditis - left ventricular endocardial fibrosis complex. J Comp Pathol. 2018; 162: 29-42.
30. Duscher GG, Hodžić A, Potkonjak A, Leschnik MW, Spergser J. Bartonella henselae and Rickettsia felis detected in cat fleas (Ctenocephalides felis) derived from eastern Austrian Cats. Vector Borne Zoonotic Dis. 2018; 18(5): 282-4.

31. Ehlers J, Krüger A, Rakotondranary SJ, Ratovonamana RY, Poppert S, Ganzhorn JU, et al. Molecular detection of Rickettsia spp., Borrelia spp., Bartonella spp. and Yersinia pestis in ectoparasites of endemic and domestic animals in southwest Madagascar. Acta Trop. 2020; 205.

32. Guptill L. Bartonellosis. Vet Clin North Am Small Anim Pract. 2003; 33: 809-25.

33. Guptill L. Bartonellosis. Vet Microbiol. 2010; 140(3-4): 347.

34. Gurfield AN, Boulouis HJ, Chomel BB, Kasten RW, Heller R, Bouillin C, et al. Epidemiology of Bartonella infection in domestic cats in France. Vet Microbiol. 2001; 80(2): 185-98.

35. Harms A, Dehio C. Intruders below the Radar: Molecular Pathogenesis of Bartonella spp. Clin Microbiol Rev. 2012; 25(1): 42-78.

36. Hobson C, Brun CL, Beauruelle C, MaakarounVermesse Z, Mereghetti L, Goudeau A, et al. Detection of Bartonella in cat scratch disease using a single-step PCR assay kit. J Med Microbiol. 2017; 66: 1596-601.

37. Iannino F, Salucci S, Provvido AD, Paolini A, Ruggieri E. Bartonella infections in humans dogs and cats. Vet Ital. 2018; 54(1): 63-72.

38. Iredell J, Blanckenberg D, Arvand M, Grauling S, Feil EJ, Birtles RJ. Characterization of the natural population of Bartonella henselae by multilocus sequence typing. J Clin Microbiol. 2003; 41(11): 5071-9.

39. Johnson A. Ocular complications of cat scratch disease. Br J Ophthalmol. 2020; 0: 1-7.

40. Kho K, Koh F, Jaafar T, Nizam QNH, Tay S. Prevalence and molecular heterogeneity of Bartonella bovis in cattle and Haemaphysalis bispinosa ticks in Peninsular Malaysia. BMC Vet Res. 2015; 1-9. 
41. Klotz SA, Ianas V, Elliott SP. Cat-scratch disease. Am Fam Physician. 2011; 83(2): 152-5.

42. Kordick DL, Hilyard EJ, Hadfield TL, Wilson KH, Steigerwalt AG, Brenner DJ, et al. Bartonella clarridgeiae, a newly recognized zoonotic pathogen causing inoculation papules, fever, and lymphadenopathy (cat scratch disease). J Clin Microbiol. 1997; 35(7): 1813-8.

43. Kosoy M, Goodrich I. Comparative ecology of Bartonella and Brucella infections in wild carnivores. Front Vet Sci. 2019; 5(January): $1-32$.

44. Ksiaa I, Abroug N, Mahmoud A, Zina S, Hedyatfar A, Attia S, et al. Update on Bartonella neuroretinitis. J Curr Ophthalmol. 2019; 31(3): 254-61.

45. Lappin MR. Update on flea and tick associated diseases of cats. Vet Parasitol. 2018; 26-9.

46. Lappin MR, Tasker S, Roura X. Role of vectorborne pathogens in the development of fever in cats, flea-associated diseases. J Feline Med Surg. 2020; 22: 31-9.

47. Latrofa MS, Iatta R, Toniolo F, Furlanello T, Ravagnan S, Capelli G, et al. A molecular survey of vector-borne pathogens and haemoplasmas in owned cats across Italy. Parasit Vectors. 2020; 13(1).

48. Liu XY, Bonnet SI. Hard tick factors implicated in pathogen transmission. PLoS Negl Trop Dis. $2014 ; 8(1)$.

49. Logan JMJ, Hall JL, Chalker VJ, O'Connell B, Birtles RJ. Bartonella clarridgeiae infection in a patient with aortic root abscess and endocarditis. Access Microbiol. 2019; 2019.1: 1-3.

50. Maggi RG, Krämer F. A review on the occurrence of companion vector-borne diseases in pet animals in Latin America. Parasit Vectors. 2019; 12.

51. Maggi RG, Ericson M, Mascarelli PE, Bradley JM, Breitschwerdt EB. Bartonella henselae bacteremia in a mother and son potentially associated with tick exposure. Parasit Vectors 2013; 6 .
52. Mascarelli PE, McQuillan M, Harms CA, Harms RV, Breitschwerdt EB. Bartonella henselae and B. koehlerae DNA in birds. Emerg Infect Dis. 2014; 20(3): 6-9.

53. Maurin M, Eb F, Etienne J., Raoult D. Serological cross-reactions between Bartonella and Chlamydia species: implications for diagnosis. J Clin Microbiol. 1997; 35(9): 2283-7.

54. Mazur-Melewska K, Mania A, Kemnitz P, Figlerowicz M, Służewski W. Cat-scratch disease: a wide spectrum of clinical pictures. Postepy Dermatol Alergol. 2015; 3: 216-20.

55. Mazurek Ł, Carbonero A, Skrzypczak M, Winiarczyk S, Adaszek Ł. Epizootic situation of feline Bartonella infection in eastern Poland. J Vet Res. 2020; 64(1): 79-83.

56. Mietze A, Morick D, Köhler H, Harrus S, Dehio C, Nolte I, et al. Combined MLST and AFLP typing of Bartonella henselae isolated from cats reveals new sequence types and suggests clonal evolution. Vet Microbiol. 2011; 148: 238-45.

57. Minnick MF, Anderson BE, editors. Molecular medical microbiology 2nd ed. Vol. 3, Animal and ectoparasitic source infections. United Kingdom: Academic Press. 2015; 1911-39 p.

58. Morelli S, Crisi PE, Cesare AD, Santis FD, Barlaam A, Santoprete G, et al. Exposure of client-owned cats to zoonotic vector-borne pathogens: clinic-pathological alterations and infection risk analysis. Comp Immunol Microbiol Infect Dis. 2019; 66.

59. Mosbacher ME, Klotz S, Klotz J, Pinnas JL. Bartonella henselae and the potential for vector-borne transmission. Vector Borne Zoonotic Dis. 2011; 11(5): 471-7.

60. Okaro U, Addisu A, Casanas B, Anderson B. Bartonella species, an emerging cause of bloodculture-negative endocarditis. Clin Microbiol Rev. 2017; 30(3): 709-46.

61. Pennisi MG, Marsilio F, Hartmann K, Lloret A, Addie D, Belák S, et al. Bartonella species infection in cats: $\mathrm{ABCD}$ guidelines on prevention and management. J Feline Med Surg. 2013; 15: 563-9. 
62. Québatte M, Dehio C. Bartonella gene transfer agent: evolution, function, and proposed role in host adaptation. Cell Microbiol. 2019; 21(May): 1-9.

63. Raoult D., Roux V. The body louse as a vector of reemerging human diseases. Clin Infect Dis. 1999; 29: 888-911.

64. Regnery R, Marano N, Jameson P. A fourth Bartonella species, Bartonella weissii, species nova, isolated from domestic cats. Paper presented at: Proceedings of the 15th Meeting of the American Society of Rickettsiology; 2000.

65. Sander A, Bühler C, Pelz K, Cramm E, Bredt W. Detection and identification of two Bartonella henselae variants in domestic cats in Germany. J Clin Microbiol. 1997; 35(3): 584-7.

66. Sanogo YO, Zeaiter Z, Caruso G, Merola F, Shpynov S, Brouqui P, et al. Bartonella henselae in Ixodes ricinus ticks (Acari: Ixodida) removed from humans, Belluno Province, Italy. Emerg Infect Dis. 2003; 9(3): 329-32.

67. Sasaki T, Pudel SKS, Isawa H, Hayashi T, Seki N, Tomita T, et al. First molecular evidence of Bartonella quintana in Pediculus humanus capitis (Phthiraptera: Pediculidae), collected from Nepalese children. J Med Entomol. 2006; 43(1): 110-2.

68. Stützer B, Hartmann K. Chronic Bartonellosis in cats: what are the potential implications? J Feline Med Surg. 2012; 14: 612-21.

69. Tamarit D, Neuvonen M, Engel P, Guy L, Andersson SGE. Origin and evolution of the Bartonella gene transfer agent. Mol Biol Evol. 2018; 35(2): 451-64.

70. Tay ST, Kho KL, Lye SF, Ngeow YF. Phylogeny and putative virulence gene analysis of Bartonella bovis. J Vet Med Sci. 2018; 80(4): 653-61.

71. Tsai Y, Chang C, Chuang S, Chomel BB. Bartonella species and their ectoparasites: selective host adaptation or strain selection between the vector and the mammalian host?. Comp Immunol Microbiol Infect Dis. 2011; 34(4): 299-314.
72. Tu N, Carroll RK, Weiss A, Shaw LN, Nicolas $\mathrm{G}$, Thomas $\mathrm{S}$, et al. A family of genusspecific RNAs in tandem with DNA-binding proteins control expression of the badA major virulence factor gene in Bartonella henselae. Microbiologyopen. 2016; 6(2).

73. Urdapilleta M, Cicuttin GL, Salvo MND, Pech-May A, Salomon OD, Lareschi M. Molecular detection and identi fication of Bartonella in the cat flea Ctenocephalides felis felis collected from companion animals in a border area in northeastern Argentina. Vet Parasitol Reg Stud Reports. 2020; 19.

74. Wikswo ME, Hu R, Metzger ME, Eremeeva MR. Detection of Rickettsia rickettsii and Bartonella henselae in Rhipicephalus sanguineus ticks from California. J Med Entomol. 2007; 44(1): 158-62.

\section{Paulè Drigotaitė, Miglè Razgūnaitė,} Jana Radzijevskaja, Algimantas Paulauskas

\section{KATĖSE APTINKAMŲ BARTONELLA SPP. PATOGENU APŽVALGA}

Santrauka

Bartonella spp. yra gramneigiamos hemotropinès bakterijos, infekuojančios daugeli gyvūnų ir žmones. Šiuo metu žinomi Bartonella spp. pernešèjai yra blusos, erkès, utèlès ir smèlio musès. Naminès katès yra pagrindiniai $B$. henselae, $B$. clarridgeiae ir B. koehlerae rezervuariniai šeimininkai. Bartonella kačių infekcijos gali pasireikšti įvairiomis formomis - nuo lengvos iki sunkios, gyvybei pavojingos ligos, tačiau dažniausiai specifinių simptomų nesukelia. Tai lemia, jog šie patogenai yra dažnai nuvertinami ar neittariami. Šioje apžvalgoje pateikiama informacija apie Bartonella bakterijų biologiją, patogeniškumą bei jų sukeliamas kačių infekcijas.

Raktažodžiai: Bartonella, katès, pernešèjų platinamos zoonozès, patogenezė 